\title{
CT-10 Nanopartículas de dióxido de titanio y aditivo hidrofóbico para mejorar las propiedades de auto-limpieza de morteros de recubrimientos
}

Nanoparticles of titanium dioxide and hydrophobic additive to improve the self-cleaning properties of coatings mortars

Susana Arrechea ${ }^{1 *}$, Jennyfer Paiz ${ }^{2}$, Luis Velásquez ${ }^{2}$

${ }^{1}$ Escuela de Ingeniería Química, Facultad de Ingeniería, Universidad de San Carlos de Guatemala y

${ }^{2}$ Centro de Investigación y Desarrollo, Cementos Progreso, Guatemala.

*Autor al que se dirige la correspondencia: arrecheausac@gmail.com

\section{Resumen}

$\mathrm{N}$ uevos morteros de textura lisa con propiedades hidrofóbicas y de auto-limpieza han sido desarrollados utilizando nanopartículas de dióxido de titanio y silicona de polisiloxano $(\mathrm{TiO} / \mathrm{Si})$. La fotocatálisis heterogénea de $\mathrm{TiO}_{2}$ es una estrategia eficiente para obtener superficies autolimpiadoras en los morteros de recubrimiento y el Si aporta propiedades hidrofóbicas. Se caracterizaron las nanopartículas de $\mathrm{TiO}_{2}$ con difracción de rayos X y se analizaron los morteros utilizando diferentes proporciones de $\mathrm{TiO}_{2} 0.5,1,3$ y $0.5 \%$ de $\mathrm{Si}$, la fase de mezclado mecánico se realizó acorde a la norma ASTM C 305-12. El estudio de termogravimetría identificó los hidratos presentes en la matriz y la temperatura de descomposición siendo esta mayor de $600^{\circ} \mathrm{C}$ para todas las muestras. Se evaluó la actividad fotocatalítica heterogénea utilizando un análisis colorimétrico y la exposición a radiación ultravioleta, para la degradación del colorante orgánico rodamina B. A edades tempranas de curado las probetas con adición de $1 \% \mathrm{TiO}_{2}-0.5 \% \mathrm{Si}$ obtuvieron mejores resultados de degradación de color. A edades tardías de curado (28 días) se observó una disminución en la actividad fotocatalítica de las muestras. Se determinaron las propiedades hidrofóbicas del mortero, mediante un análisis de ángulo de contacto y permeabilidad utilizando el tubo de Karsten. Este estudio demuestra que los morteros que contienen TiO2-Si presentan propiedades autolimpiantes y propiedades humectantes que favorecen la limpieza de partículas sueltas con el agua de lluvia.

Palabras claves: Silicona de polisiloxano, difracción de rayos X, propiedades humectantes

\section{Abstract}

$\mathrm{N}$ ew smooth-texture mortars with hydrophobic and self-cleaning properties have been developed using titanium dioxide nanoparticles and polysiloxane $(\mathrm{TiO} 2 / \mathrm{Si})$. Heterogeneous photocatalysis of $\mathrm{TiO} 2$ is an efficient strategy to obtain self-cleaning surfaces in coating mortars and Si provides hydrophobic properties. The TiO2 nanoparticles were characterized by X-ray diffraction and the mortar was analyzed using different $\mathrm{TiO} 2$ ratios $0.5 \%, 1 \%, 3 \%$ and $0.5 \%$ of Si. The mechanical mixing phase was performed according to ASTM C 305- 12 . The thermogravimetry study identified the hydrates found in the matrix and the decomposition temperature, which is higher than $600^{\circ} \mathrm{C}$ for all samples. Heterogeneous photocatalytic activity was evaluated through a colorimetric analysis and exposure to ultraviolet radiation for the degradation of the organic dye Rhodamine B. At early ages of curing of specimens $1 \% \mathrm{TiO} 2-0.5 \% \mathrm{Si}$ better results of color degradation were obtained. At late ages of curing of specimens (28 days) a decrease in the photocatalytic activity of the samples was observed. The hydrophobic properties of the mortar were determined by a contact angle and permeability analysis by using the Karsten tube. This study demonstrates that mortars containing $\mathrm{TiO} 2-\mathrm{Si}$ exhibit self-cleaning properties and wetting properties that benefit the cleaning of loose particles with rainwater. 